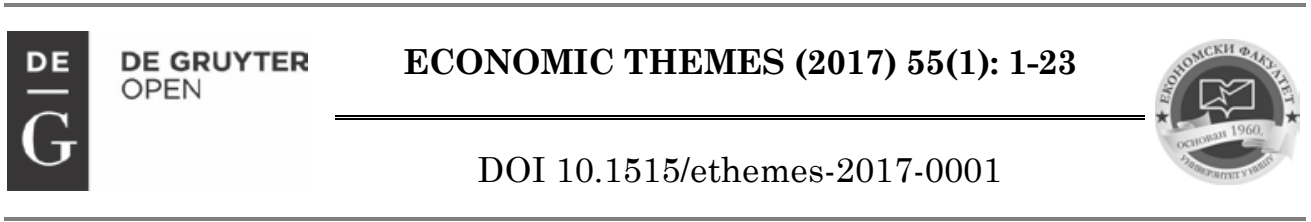

\title{
EFFECTS OF FOREIGN DIRECT INVESTMENTS ON SERBIAN EXPORTERS' PROFITABILITY
}

\author{
Violeta Domanović ${ }^{*}$ \\ University of Kragujevac, Faculty of Economics, Republic of Serbia \\ $\bowtie$ violeta.domanovic@gmail.com \\ Sandra Stojadinović Jovanović \\ University of Belgrade, Faculty of Economics, Republic of Serbia \\ $\bowtie$ sandra28@gmail.com \\ UDC \\ 339.727.22( \\ 497.11) \\ Original \\ scientific \\ paper

\begin{abstract}
For Serbia the efforts to attract investments from abroad came to the fore with the beginning of transition process. The process of ownership transformation in Serbia most often implied foreign direct investment inflows, because it included participation of foreign investors in purchase of domestic companies that had been the subject of privatisation. The subject of research in the paper is Serbian experience in attracting foreign capital into local export companies with special emphasis on their profitability. Aim of the paper is to estimate the profitability of leading Serbian exporters financed by foreign direct investments, i.e. to determine whether and to what extent foreign direct investments contributed to the increase of return on assets (ROA) and return on equity (ROE), as basic profitability measures. The results show that, in the case of Serbian exporters, the profitability varies, both per companies and per individual years. There is no general conclusion that foreign direct investments contributed to the ROA increase. On the contrary, ROA values significantly varied during this period. Either enormous increase or enormous decrease could be observed. The same goes for ROE values.
\end{abstract}

Received:

15.07.2016.

Accepted:

17.03.2017.
Keywords: exporters, foreign direct investments, profitability, return on assets, return on equity, Serbia.

JEL classification: M21, F21, F23

* The paper is a part of the research done within the project No 41010 and No.179062 of the Serbian Ministry of Education, Science and Technological Development. 


\section{Introduction}

Serbia's economy belongs to transition economies that have a great need for foreign investments. For Serbia, as well as for other countries in transition, the efforts to attract investments from abroad came to the fore with the beginning of transition process and the emergence of need for providing additional resources for economic restructuring and acceleration of economic growth. The crucial part of the transition process and these countries' reforms was the process of ownership transformation in their economies. These are the economies in which the transformation of a state property into a private property and privatisation process were the primary channel for foreign direct investment inflows.

Inflows of foreign direct investment (FDI) can be realised through Greenfield/Brownfield investments, joint ventures or mergers and acquisitions. The latter (M\&A) were the most common in transition economies, including Serbia, and were performed through privatisation. The process of ownership transformation in Serbia most often implied such participation of foreign investors by which they were directly included in this process, via purchase of domestic companies that were the subjects of privatisation.

Inflows of FDI have been very significant for the Serbian economy and companies since the first decade of the twenty-first century. Since 2001, FDI inflows in Serbia have been growing considerably (with the exception of 2004) and reached their maximal value of 4.2 billion USD in 2006, when Serbia was the CEE region country with the highest FDI inflow. That was followed by a four-year long decrease (to the level of 1.3 billion USD) which lasted until 2010, then the recovery in 2011 (to 2.7 billion USD) and then again a drastic decrease in 2012 (to 0.3 billion USD). In 2013, FDI inflows made progress, exceeding 1 billion USD (NBS, 2016). Among the closest SEE countries (Albania, Bosnia and Herzegovina, Montenegro and Macedonia), Serbia has had the highest FDI inflow, both annual FDI and total FDI inflow (UNCTAD FDI database). However, that value is significantly smaller than the value of FDI inflows of other more advanced transition countries (such as Bulgaria, Czech Republic, Hungary, Poland, Romania, Slovakia or Croatia). The conclusion is the same if the FDI average inflows of SEE economies are compared (UNCTAD FDI database).

The major part of FDI inflows in Serbia, as in other transition countries, was connected to privatisation. The largest FDI in Serbia (such as Telenor, NIS, DIN and DIV, Stada) were attracted exactly by the privatisation process. After the world crisis, the dominant interest was given to strategic partnership through joint venture (Fiat, Jura, Beneton), followed by considerable budget incentives (Privatisation Agency, 2013).

The effects of foreign capital inflow into the countries in transition, particularly the sale of domestic companies to foreign investors with majority foreign 
ownership (FDI), have been the subjects of numerous studies in literature, including theoretical and empirical researches. For this reason, the subject of research in the paper is the experience of the Republic of Serbia in attracting foreign capital into Serbian companies, primarily export companies which represent the essence of each economy and its influence on exporters' profitability. Those are the companies in which FDI was undertaken and majority foreign ownership accomplished in the previous period.

The aim of research is measuring and analysis of the effects of foreign direct investment on profitability of companies in the Republic of Serbia, i.e. determining whether and to what extent foreign direct investments contributed to the increase of return on assets (ROA) and return on equity (ROE), as basic profitability measures. Profitability of a company represents the most comprehensive expression of business efficiency and incorporates all the elements and factors that influence both productivity and economy, as the first and second partial expression of the business efficiency.

For a long time, the researchers have been facing the problem of performance measures selection. In the modern business environment, it is very important to define the appropriate variables and dimensions in the process of business excellence measurement. This is the consequence of the necessity that new management models and organisational development must be aligned with the competitive challenges in the 21st century.

In terms of very dynamic and unpredictable business environment, nonfinancial measures become more significant in the process of the company's success evaluation as well as the integrated models such as Balanced Scorecard (Kaplan \& Norton, 1992, 1993, 1996). This kind of a model enables the observation of the company's success from several aspects. Traditionally, the company's success is evaluated according to traditional financial measures derived from accounting reports. Such measures are focussed on the past and the realised results. In contemporary business environment it is not enough anymore. The managers must be able to predict what exactly would contribute to financial success in future. However, the question is what the most important performance measures are in the case when there are various forms of foreign direct investments. In order to examine if foreign direct investment is economically reasonable or not, the typically used performance measures are return on assets (ROA) and return on equity (ROE).

The starting hypothesis is that the attraction of foreign capital contributes to the increase of profitability of the company with FDI inflow. The starting hypothesis can be divided into two supporting hypotheses:

H1. Companies which experience the inflow of foreign direct investments accomplish a positive trend in dynamics of return on assets (ROA) values. 
H2. Companies which experience the inflow of foreign direct investments accomplish a positive trend in dynamics of return on equity (ROE) values.

For the purpose of testing the starting hypotheses, quantitative methodology was applied in the paper. The paper has two structural parts. The first part provides an overview of theoretical and empirical considerations of the effects of FDI inflow and measuring of company's performance. The second part elaborates the results of the conducted research.

\section{Theoretical Background}

Performance measurement and performance management have been the actual and widespread research area in the field of business economics and management and management accounting for more than two decades. There have been numerous discussions among researchers and practitioners in domestic and foreign literature, as well. Some authors (Kennerly \& Neely, 2003) considered the strategic performance measurement, which could be defined as a system of measurement and reporting, which quantifies the degree at which managers achieve defined aims. Performance measurement makes possible clarification of the mission and vision of any company and translation of the strategy into measurable aims and objectives. That is why a company should not just measure the progress in the aim realisation, but should also understand what leads to the results improvement. Besides, performance measurement implies the fortification of responsibilities, making of decision on improvement and alignment of operation activities and resources with the strategic aims. The planned activities would be understood better and there would be a clear communication of the expectations at all organisational levels.

The very important issue is what kind of performance system might be considered as a successful one in a contemporary business environment (Paranjape et al., 2006). A successful performance system is a set of performance measures (i.e. a metric used to quantify the efficiency and effectiveness of action) that provides a company with useful information in order to manage the activities undertaken in the company. The information retrieved from the performance measurement systems must in turn be accurate, relevant, timely (provided at the right time) and easily accessible for the persons who need it. Furthermore, performance measures must also be designed to reflect the most important factors influencing the productivity of the different processes that can be found in the company. Designing of such a performance measurement system is a difficult task and what can be considered as the optimal performance measurement system will also differ from case to case (Tangen, 2005).

Performance measurement systems would differ from one company to the other, depending on their specific and unique needs. Also, performance 
measurement has been evolving throughout its history respecting not just the needs of a specific company but also specific features of the business environment. The question is what the challenges of measuring business excellence in the twenty-first century business background are.

The recession and the related economic and production difficulties that companies are dealing with require a deep reconsideration of the business models and managerial approaches adopted to govern the company's growth and valuecreation processes. Modern business environment, which is complex, dynamic, turbulent, and heterogeneous, simply forces the management to introduce some new models and frameworks for performance measurement and management. In the twentieth century, the effort of the modern management had been aimed at developing a wide range of models to allow managers to control, understand and coordinate the functions of the company's value chain, as well as their integration in accordance with a strategic perspective (see Table 1).

Table 1. Literature review of performance measurement and management models

\begin{tabular}{|c|c|c|}
\hline $\begin{array}{c}\text { Period of } \\
\text { introduction } \\
\end{array}$ & Name of the model/framework & References \\
\hline Before 1980s & The ROI, ROE, ROCE and derivates & Simons (2000) \\
\hline \begin{tabular}{|l|}
1980 \\
\end{tabular} & The Economic Value Added (EVA) & Stewart (2007) \\
\hline 1988 & The Activity-Based Costing - The Activity Based Management & Cooper and Kaplan (1988) \\
\hline 1988 & The Strategic Measurement Analysis and Reporting Techniques (SMART) & Cross and Lynch (1988) \\
\hline 1989 & The Supportive Performance Measures (SPA) & Keegan et al. (1989) \\
\hline 1990 & The Customer Value Analysis (CVA) & Customer Value Inc. (2007) \\
\hline 1990 & The Performance Measurement Questionnaire (PMQ) & Dixon et al. (1990) \\
\hline 1991 & The Results and Determinants Framework (RDF) & Fitzgerald et al. (1991) \\
\hline 1992 & The Balanced Scorecard (BSC) & Kaplan and Norton (1992) \\
\hline 1994 & The Service-Profit Chain (SPC) & Heskett et al. (1994) \\
\hline 1995 & The Return on Quality Approach (ROQ) & Rus et al. (1995) \\
\hline 1996 & The Cambridge Performance Measurement Framework (CPMF) & Neely et al. (1996) \\
\hline 1996 & The Consistent Performance Measurement System (CPMS) & Flapper et al. (1996) \\
\hline 1997 & The Integrated Performance Measurement System (IPMS) & Bititci et al. (1997) \\
\hline 1998 & The Comparative Business Scorecard (CBS) & Kanji (1998) \\
\hline 1998 & The Integrated Performance Measurement Framework (IPMF) & Medori and Steeple (2000) \\
\hline 1999 & The Business Excellence Model (BEM) & EFQM (2007) \\
\hline 2000 & The Dynamic Performance Measurement System (DPMS) & Bititci et al. (2000) \\
\hline 2001 & The Action-Profit Linkage Model (APL) & Epstein and Westbrook (2001) \\
\hline 2001 & The Manufacturing System Design Decomposition (MSDD) & Cochran et al. (2001) \\
\hline 2001 & The Performance Prism (PP) & Neely et al. (2001) \\
\hline 2004 & The Performance Planning Value Chain (PPVC) & Neely and Jarrar (2004) \\
\hline 2004 & $\begin{array}{l}\text { The Capability Economic Value of Intangible and Tangible Assets } \\
\text { (CEVITA) }\end{array}$ & Ratnatunga et al. (2004) \\
\hline 2006 & $\begin{array}{l}\text { The Performance, Development, Growth Benchmarking System } \\
\text { (PDGBS) }\end{array}$ & St-Pierre and Delisle (2006) \\
\hline 2007 & The Unused Capacity Decomposition Framework (UCDF) & Balachandran et al. (2007) \\
\hline
\end{tabular}

Source: Adapted from Taticchi, P., Tonelli, F., \& Cagnazzo, L. (2010). Performance measurement and management: A literature review and research agenda. Measuring Business Excellence, 14(1), 10. 
All these models might be classified into three groups (Tangen, 2005, 48):

- The first group encompasses all those models which use mostly traditional performance measures, such as ROA, ROE, cash flow performance measures. These measures are mainly directed on accounting data, short term and past oriented.

- The second group encompasses all those models which have more balanced and holistic view on performance than the previous ones. Nonfinancial measures are used, i.e. this group has a multidimensional view of performance from different perspectives and time horizons: long-term and short-term and most hierarchical levels are covered.

- The third group encompasses the most advanced models, which means that very high standards are met and that the needs from all relevant stakeholders are considered. Databases and other reporting systems should be fully integrated into one another. The information in the models is updated continuously and directly presented to the persons who need it.

Generally, each business activity and business process has impact on some kind of company's performance. Performance could be considered from various aspects. It could be about strategic performance, organisational performance, technical performance, financial performance, human capital performance and so on. However, if we want to examine the economic justification of some business and managerial decision, we should ask ourselves whether this kind of decision would contribute, and to what extent, to the profitability increase. Why just profitability? In the market economy, profit is the comprehensive and the most important indicator of company's efficiency. Thus, if there are foreign direct investments in some company, the question is how it affects its performance, and especially profitability, as the final aim of the company functioning in the long term.

In theoretical and empirical researches, broad attention is paid to the analysis of FDI effects. FDI inflows might bring many positive effects to the economies of host countries, such as effects of transfers of various resources (capital, technology, and management), effects on the balance of payments, competition, economic growth, industrial structure, entrepreneurship, employment and trade. Caves (1974, 1996) observes several positive effects of FDI including productivity gains, transfer of technology, managerial skills and know-how and access to international production network and market. Rappaport (2000) observes that FDI improves productivity of both the companies that receive FDI and also all other host country companies due to technological spillovers. Hunya (2000) highlights FDI impacts on competitiveness and on growth and restructuring in Central European transition countries (Hunya, 2002). Kalotay (2010) emphasises the contribution of FDI to structural changes in different groups of transition countries.

The positive effects that FDI might bring stimulate countries to try to attract more FDI inflows, especially in the case of Serbia and other transition economies 
which suffer from the lack of domestic investments and resources and, therefore, have the huge need for foreign investment.

Inflows of foreign investments in Serbia and other transition economies have primarily developed through privatisation process. This process in transition countries most often implied such participation of foreign investors by which they were directly included in the process, via purchase of domestic companies that were the subject of privatisation.

Inflows of foreign investment were stimulated by transition economies governments themselves for the numerous reasons including economic ones, and starting with the fact that the sale of state companies to private investors (especially foreign ones) would improve the company's performance, as a consequence of better discipline implied by private ownership. The results of many researches show that privatised companies accomplish better business performances compared with state-owned companies, especially the one privatised by the foreign investors (which experienced FDI inflows). So, there are findings which show that privatisation is "efficient", but only when the company is controlled by external owners (outsiders), and that externally controlled companies grow faster (Frydman et al., 1999). The overview of privatised companies in various countries of Central Europe shows that the only companies that realised strategic restructuring are the ones that are in majority foreign ownership. The crucial reason why external ownership is a necessary condition for restructuring can be explained by inability of companies to increase the requested equity sum and pay for the expertise in conditions of interior (insider) ownership (Aghion \& Blanchard, 1998).

That is confirmed by studies which show a positive influence of foreign companies (companies which, after privatisation, became companies in majority foreign ownership) on productivity of a domestic economy, as well as their positive role in the improvement of economic welfare and life standard. There are findings which indicate that $1 \%$ increase of foreign ownership leads to $3,9 \%$ increase of value added, while for employees' ownership that increase amounts to $1,4 \%$, and that companies with higher income, profit and export are more likely to be in foreign ownership (Smith et al., 1997); there are also findings which show that foreign-owned companies invest more in comparison with domestically-owned companies and have stronger influence on restructuring (Lizal \& Svejnar, 2001), and there are those which point out that presence of one major foreign owner (in the sense of higher ownership concentration effects) contributes significantly to the productivity increase (Grosfeld \& Tressel, 2002). Lizal and Svejnar (2002) perceive that foreign owners definitely improve long-term performances (including profit and investments) of privatised companies, while domestic owners do not manage to do that. Kocenda and Svejnar (2002) establish that foreign ownership concentration improves economic performances, unlike domestic private ownership, compared with state-owned companies, and also that foreign-controlled 
companies implement strategic restructuring together with the increase of sales and profit, while domestic companies reduce sales and work costs without the increase of profit.

As it can be observed the FDI effects have been the subject of special attention in a number of researches and they are important on both economy and company level. Our paper is focused on export companies as exporters are the core of national economy providing foreign exchange inflow, base for higher production and employment and higher living standards. That is why our analysis will be focused on export companies - those in which there has been an inflow of FDI and which are in majority foreign ownership.

\section{Materials and Methods}

The research was conducted by collecting data on Serbian exporters and selecting a sample of 11 leading exporters among them, but only those that had previously received direct investments from abroad. In the first step, we researched the companies' ownership (using the data of Serbian Business Register Agency), among the largest exporters of Serbia and selected 11 companies that are majority foreign-owned. In the second step, the data on relevant indicators of the selected exporters on the Serbian market, financed by foreign direct investments, were obtained from the available basic financial statements of these companies published by Serbian Business Register Agency. Third, the calculation of relevant indices, based on these financial data, allowed us to estimate the profitability of leading Serbian exporters financed by foreign direct investments.

The company Fiat Automobili d.o.o. Kragujevac (FCA Srbija d.o.o. Kragujevac) became majority foreign-owned (66.7\%) in 2008 with foreign investment inflow of 940 million EUR. The company Tigar Tyres d.o.o. Pirot became wholly foreign-owned (100\%) company through foreign direct investment value of 132 million EUR in 2002. The company Nis a.d. Novi Sad became majority-foreign owned (56.1\%) in 2008 through foreign investment inflow of 947 million EUR. The company Hemofarm a.d. Vršac became wholly-foreign owned (100\%) company in 2006 through foreign direct investment inflow of 650 million EUR. The company Valjaonica Bakra, Sevojno became majority-foreign owned (80.9\%) from 2004 through initial foreign investment value of about 3 million EUR. The company Impol Seval a.d., Sevojno, became majority-foreign owned (70\%) in 2002 through initial investment value of 6.5 million USD. The company Siemens d.o.o. Beograd was established in 1996 as a wholly-foreign owned (100\%) company through greenfield investment with initial investment value of 2.386 million EUR. The company Tarkett d.o.o. Bačka Palanka is wholly-foreign owned (100\%) from 2002 with foreign investment value of 136 million EUR. The company Ball Pakovanja Evropa Beograd d.o.o. was founded as a wholly-foreign 
owned (100\%) company through greenfield investment in 2004 with investment value of 100 million EUR. The company Valy d.o.o. Valjevo was founded in 2001 as a wholly-foreign owned (100\%) company through greenfield investment value of 15 million EUR. The company Tetra Pak Production d.o.o. Beograd is whollyforeign owned (100\%) from 1996 through brownfield investment of 72 million EUR. Data are given according to the authors' own research regarding each individual company. It can be observed that all companies received FDI and became majority (or wholly) foreign-owned before 2009, and therefore the analysis includes the period since 2009.

For the purpose of estimation of company's profitability, two measures were selected; they are ROA (Return on Assets) and $R O E$ (Return on Equity). ROA was obtained as the ratio of operating income/operating loss (from Income statement) and total assets value (from Balance sheet). ROA can have a positive or negative value in dependence on whether the company achieved operating income or operating loss and it shows return/operating loss on 100 dinars of assets. ROE was obtained as the ratio of net income/net loss (from Income statement) and total equity (from Balance sheet), which represents a balanced expression of shareholders' equity, retained profit, unrealised losses from securities and loss. The research follows the trend of ROA and ROE in the last five-year period 2009-2015. Dynamics of ROA and ROE will be observed via chain indices which will be obtained as ratio of ROA and ROE in the current year and value of ROA and ROE in the previous year.

Table 2. Leading Serbian exporters financed by foreign direct investments - the appropriate data on total assets

\begin{tabular}{|c|c|c|c|c|c|c|c|c|c|}
\hline \multirow{2}{*}{ Company } & \multirow{2}{*}{ Activity } & \multirow{2}{*}{$\begin{array}{c}\text { Share in } \\
\text { Serbia's } \\
\text { export } \\
2012 \\
\end{array}$} & \multicolumn{7}{|c|}{$\begin{array}{c}\text { Balance sheet TOTAL ASSETS } \\
\text { (in } 000000 \text { dinars) }\end{array}$} \\
\hline & & & 2015 & 2014 & 2013 & 2012 & 2011 & 2010 & 2009 \\
\hline $\begin{array}{l}\text { Fiat } \\
\text { Automobili } \\
\text { d.o.o. } \\
\text { Kragujevac } \\
\end{array}$ & $\begin{array}{l}\text { Production of } \\
\text { cars }\end{array}$ & 3,48 & 110.763 & 124.662 & 144.383 & 145.308 & 78.790 & 40.450 & 34.442 \\
\hline $\begin{array}{l}\text { Tigar Tyres } \\
\text { d.o.o., Pirot }\end{array}$ & $\begin{array}{l}\text { Production of } \\
\text { vehicle tyres }\end{array}$ & 1,96 & 49.036 & 35.976 & 24.280 & 19.721 & 18.080 & 15.487 & 12.080 \\
\hline $\begin{array}{l}\text { Nis A.D. } \\
\text { Novi Sad } \\
\end{array}$ & $\begin{array}{l}\text { Extraction of } \\
\text { crude oil }\end{array}$ & 1,91 & 376.668 & 372.211 & 350.501 & 295.432 & 232.703 & 177.127 & 144.051 \\
\hline $\begin{array}{l}\text { Hemofarm } \\
\text { a.d Vršac }\end{array}$ & $\begin{array}{l}\text { Production of } \\
\text { pharmaceutical } \\
\text { preparations } \\
\end{array}$ & 1,77 & 33.929 & 33.245 & 33.137 & 36.328 & 35.036 & 41.763 & 39.052 \\
\hline $\begin{array}{l}\text { Valjaonica } \\
\text { Bakra }\end{array}$ & $\begin{array}{l}\text { Processing of } \\
\text { copper }\end{array}$ & 1,54 & 6.653 & 6.651 & 7.546 & 12.313 & 10.966 & 11.474 & 9.383 \\
\hline $\begin{array}{l}\text { Impol Seval } \\
\text { a.d., Sevojno }\end{array}$ & $\begin{array}{l}\text { Processing of } \\
\text { aluminium }\end{array}$ & 1,36 & 8.874 & 8.958 & 8.557 & 8.493 & 7.550 & 6.871 & 5.105 \\
\hline $\begin{array}{l}\text { Siemens } \\
\text { d.o.o. } \\
\text { Beograd } \\
\end{array}$ & $\begin{array}{l}\text { Wholesale of } \\
\text { other } \\
\text { machines }\end{array}$ & 1,34 & 5.436 & 6.129 & 4.777 & 5.522 & 4.035 & 3.027 & 2.820 \\
\hline $\begin{array}{l}\text { Tarkett } \\
\text { d.o.o. } \\
\text { Backa } \\
\text { Palanka } \\
\end{array}$ & $\begin{array}{l}\text { Production of } \\
\text { construction } \\
\text { industry } \\
\text { elements } \\
\end{array}$ & 1,27 & 12.710 & 14.437 & 15.947 & 16.888 & 14.499 & 13.053 & 19.340 \\
\hline
\end{tabular}




\begin{tabular}{|l|l|c|c|c|c|c|c|c|c|}
\hline $\begin{array}{l}\text { Ball } \\
\begin{array}{l}\text { Pakovanja } \\
\text { Evropa } \\
\text { Beograd, } \\
\text { d.o.o. }\end{array}\end{array}$ & $\begin{array}{l}\text { Production of } \\
\text { light metal } \\
\text { packaging }\end{array}$ & 1,26 & 17.648 & 14.699 & 13.412 & 12.060 & 10.095 & 9.101 & 7.422 \\
\hline $\begin{array}{l}\text { Valy d.o.o. } \\
\text { Valjevo }\end{array}$ & $\begin{array}{l}\text { Production of } \\
\text { knitted and } \\
\text { crocheted } \\
\text { socks }\end{array}$ & 1,15 & 14.117 & 14.414 & 12.110 & 12.564 & 11.727 & 8.975 & 8.301 \\
\hline $\begin{array}{l}\text { Tetra Pak } \\
\begin{array}{l}\text { Production } \\
\text { d.o.o. } \\
\text { Beograd }\end{array}\end{array}$ & $\begin{array}{l}\text { Production of } \\
\text { corrugated } \\
\text { paper and } \\
\text { packaging }\end{array}$ & 1,01 & 8.506 & 7.608 & 6.283 & 5.040 & 4.648 & 5.194 & 6.813 \\
\hline
\end{tabular}

Source: Authors' research based on data from SBRA (2016)

Table 3. Leading Serbian exporters financed by foreign direct investments - data on operating income

\begin{tabular}{|c|c|c|c|c|c|c|c|c|c|}
\hline \multirow{2}{*}{ Company } & \multirow{2}{*}{ Activity } & \multirow{2}{*}{$\begin{array}{l}\text { Share in } \\
\text { Serbia's } \\
\text { export } \\
2012\end{array}$} & \multicolumn{7}{|c|}{$\begin{array}{c}\text { Balance sheet TOTAL ASSETS } \\
\text { (in } 000000 \text { dinars) }\end{array}$} \\
\hline & & & 2015 & 2014 & 2013 & 2012 & 2011 & 2010 & 2009 \\
\hline $\begin{array}{l}\text { Fiat } \\
\text { Automobili } \\
\text { d.o.o. } \\
\text { Kragujevac } \\
\end{array}$ & $\begin{array}{l}\text { Production of } \\
\text { cars }\end{array}$ & 3,48 & 2.189 & 3.918 & 2.199 & -4.925 & -5.419 & -406 & 196 \\
\hline $\begin{array}{l}\text { Tigar Tyres } \\
\text { d.o.o., Pirot }\end{array}$ & $\begin{array}{l}\text { Production of } \\
\text { vehicle tyres }\end{array}$ & 1,96 & 7.192 & 5.012 & 5.881 & 3.380 & 2.957 & 3.614 & 2.902 \\
\hline $\begin{array}{l}\text { Nis A.D. } \\
\text { Novi Sad }\end{array}$ & $\begin{array}{l}\text { Extraction of } \\
\text { crude oil }\end{array}$ & 1,91 & 23.924 & 50.741 & 56.830 & 64.981 & 41.069 & 26.190 & -2.101 \\
\hline $\begin{array}{l}\text { Hemofarm } \\
\text { a.d Vršac }\end{array}$ & $\begin{array}{l}\text { Production of } \\
\text { pharmaceutic } \\
\text { al } \\
\text { preparations }\end{array}$ & 1,77 & 3.868 & 4.447 & 3.463 & 4.915 & 4.494 & 2.323 & 4.244 \\
\hline $\begin{array}{l}\text { Valjaonica } \\
\text { Bakra }\end{array}$ & $\begin{array}{l}\text { Processing of } \\
\text { copper }\end{array}$ & 1,54 & 333 & 46 & 215 & 552 & 495 & 428 & 459 \\
\hline $\begin{array}{l}\text { Impol Seval } \\
\text { a.d., } \\
\text { Sevojno }\end{array}$ & $\begin{array}{l}\text { Processing of } \\
\text { aluminium }\end{array}$ & 1,36 & 1.134 & 435 & 442 & 732 & 854 & 767 & 84 \\
\hline $\begin{array}{l}\text { Siemens } \\
\text { d.o.o. } \\
\text { Beograd }\end{array}$ & $\begin{array}{l}\text { Wholesale of } \\
\text { other } \\
\text { machines }\end{array}$ & 1,34 & 428 & 584 & 356 & 505 & 174 & -5 & 188 \\
\hline $\begin{array}{l}\text { Tarkett } \\
\text { d.o.o. } \\
\text { Backa } \\
\text { Palanka } \\
\end{array}$ & $\begin{array}{l}\text { Production of } \\
\text { construction } \\
\text { industry } \\
\text { elements }\end{array}$ & 1,27 & -153 & 1.339 & 2.639 & 2.659 & 2.234 & 2.777 & 1.920 \\
\hline $\begin{array}{l}\text { Ball } \\
\text { Pakovanja } \\
\text { Evropa } \\
\text { Beograd, } \\
\text { d.o.o. }\end{array}$ & $\begin{array}{l}\text { Production of } \\
\text { light metal } \\
\text { packaging }\end{array}$ & 1,26 & 1.594 & 1.164 & 1.259 & 1.262 & 257 & 692 & 726 \\
\hline $\begin{array}{l}\text { Valy d.o.o. } \\
\text { Valjevo }\end{array}$ & $\begin{array}{l}\text { Production of } \\
\text { knitted and } \\
\text { crocheted } \\
\text { socks }\end{array}$ & 1,15 & 127 & 99 & 130 & 293 & -84 & 505 & 240 \\
\hline $\begin{array}{l}\text { Tetra Pak } \\
\text { Production } \\
\text { d.o.o. } \\
\text { Beograd } \\
\end{array}$ & $\begin{array}{l}\text { Production of } \\
\text { corrugated } \\
\text { paper and } \\
\text { packaging }\end{array}$ & 1,01 & 4.622 & 3.334 & 2.162 & 2.399 & 1.532 & 2.824 & 3.379 \\
\hline
\end{tabular}

Source: Authors' research based on data from SBRA (2016) 
Table 4. Leading Serbian exporters financed by foreign direct investments - data on net income

\begin{tabular}{|c|c|c|c|c|c|c|c|c|c|}
\hline \multirow{2}{*}{ Company } & \multirow{2}{*}{ Activity } & \multirow{2}{*}{$\begin{array}{l}\text { Share in } \\
\text { Serbia's } \\
\text { export } \\
2012\end{array}$} & \multicolumn{7}{|c|}{$\begin{array}{l}\text { NET INCOME (NET LOSS) } \\
\text { (in } 000000 \text { dinars) }\end{array}$} \\
\hline & & & 2015 & 2014 & 2013 & 2012 & 2011 & 2010 & 2009 \\
\hline $\begin{array}{l}\text { Fiat } \\
\text { Automobili } \\
\text { d.o.o. } \\
\text { Kragujevac } \\
\end{array}$ & $\begin{array}{l}\text { Production of } \\
\text { cars }\end{array}$ & 3,48 & 2.189 & 3.918 & 2.199 & -4.925 & -5.419 & -406 & 196 \\
\hline $\begin{array}{l}\text { Tigar Tyres } \\
\text { d.o.o., Pirot }\end{array}$ & $\begin{array}{l}\text { Production of } \\
\text { vehicle tyres }\end{array}$ & 1,96 & 7.192 & 5.012 & 5.881 & 3.380 & 2.957 & 3.614 & 2.902 \\
\hline $\begin{array}{l}\text { Nis A.D. } \\
\text { Novi Sad }\end{array}$ & $\begin{array}{l}\text { Extraction of } \\
\text { crude oil }\end{array}$ & 1,91 & 23.924 & 50.741 & 56.830 & 64.981 & 41.069 & 26.190 & -2.101 \\
\hline $\begin{array}{l}\text { Hemofarm } \\
\text { a.d Vršac }\end{array}$ & $\begin{array}{l}\text { Production of } \\
\text { pharmaceutic } \\
\text { al } \\
\text { preparations }\end{array}$ & 1,77 & 3.868 & 4.447 & 3.463 & 4.915 & 4.494 & 2.323 & 4.244 \\
\hline $\begin{array}{l}\text { Valjaonica } \\
\text { Bakra } \\
\end{array}$ & $\begin{array}{l}\text { Processing of } \\
\text { copper }\end{array}$ & 1,54 & 333 & 46 & 215 & 552 & 495 & 428 & 459 \\
\hline $\begin{array}{l}\text { Impol Seval } \\
\text { a.d., } \\
\text { Sevojno }\end{array}$ & $\begin{array}{l}\text { Processing of } \\
\text { aluminium }\end{array}$ & 1,36 & 1.134 & 435 & 442 & 732 & 854 & 767 & 84 \\
\hline $\begin{array}{l}\text { Siemens } \\
\text { d.o.o. } \\
\text { Beograd }\end{array}$ & $\begin{array}{l}\text { Wholesale of } \\
\text { other } \\
\text { machines }\end{array}$ & 1,34 & 428 & 584 & 356 & 505 & 174 & -5 & 188 \\
\hline $\begin{array}{l}\text { Tarkett } \\
\text { d.o.o. } \\
\text { Backa } \\
\text { Palanka } \\
\end{array}$ & $\begin{array}{l}\text { Production of } \\
\text { construction } \\
\text { industry } \\
\text { elements }\end{array}$ & 1,27 & -153 & 1.339 & 2.639 & 2.659 & 2.234 & 2.777 & 1.920 \\
\hline $\begin{array}{l}\text { Ball } \\
\text { Pakovanja } \\
\text { Evropa } \\
\text { Beograd, } \\
\text { d.o.o. } \\
\end{array}$ & $\begin{array}{l}\text { Production of } \\
\text { light metal } \\
\text { packaging }\end{array}$ & 1,26 & 1.594 & 1.164 & 1.259 & 1.262 & 257 & 692 & 726 \\
\hline $\begin{array}{l}\text { Valy d.o.o. } \\
\text { Valjevo }\end{array}$ & $\begin{array}{l}\text { Production of } \\
\text { knitted and } \\
\text { crocheted } \\
\text { socks }\end{array}$ & 1,15 & 127 & 99 & 130 & 293 & -84 & 505 & 240 \\
\hline $\begin{array}{l}\text { Tetra Pak } \\
\text { Production } \\
\text { d.o.o. } \\
\text { Beograd }\end{array}$ & $\begin{array}{l}\text { Production of } \\
\text { corrugated } \\
\text { paper and } \\
\text { packaging }\end{array}$ & 1,01 & 4.622 & 3.334 & 2.162 & 2.399 & 1.532 & 2.824 & 3.379 \\
\hline
\end{tabular}

Source: Authors' research based on data from SBRA (2016)

Table 5. Leading Serbian exporters financed by foreign direct investments-data on equity

\begin{tabular}{|c|c|c|c|c|c|c|c|c|c|}
\hline \multirow[t]{2}{*}{ Company } & \multirow[t]{2}{*}{ Activity } & \multirow{2}{*}{$\begin{array}{c}\text { Share in } \\
\text { Serbia's } \\
\text { export } \\
2012\end{array}$} & \multicolumn{7}{|c|}{$\begin{array}{l}\text { EQUITY }(102+103+104+105+106-107+108-109-110) \\
\text { (in } 000000 \text { dinars) }\end{array}$} \\
\hline & & & 2015 & 2014 & 2013 & 2012 & 2011 & 2010 & 2009 \\
\hline $\begin{array}{l}\text { Fiat } \\
\text { Automobili } \\
\text { d.o.o. } \\
\text { Kragujevac } \\
\end{array}$ & $\begin{array}{l}\text { Production of } \\
\text { cars }\end{array}$ & 3,48 & 27.140 & 23.866 & 23.211 & 22.668 & 24.911 & 30.994 & 28.990 \\
\hline $\begin{array}{l}\text { Tigar Tyres } \\
\text { d.o.o., Pirot }\end{array}$ & $\begin{array}{l}\text { Production of } \\
\text { vehicle tyres }\end{array}$ & 1,96 & 29.042 & 22.137 & 17.172 & 13.873 & 11.114 & 8.502 & 6.778 \\
\hline
\end{tabular}




\begin{tabular}{|c|c|c|c|c|c|c|c|c|c|}
\hline $\begin{array}{l}\text { Nis A.D. } \\
\text { Novi Sad }\end{array}$ & $\begin{array}{l}\text { Extraction of } \\
\text { crude oil }\end{array}$ & 1,91 & 203.015 & 194.586 & 176.883 & 137.003 & 87.587 & 47.019 & 32.283 \\
\hline $\begin{array}{l}\text { Hemofarm } \\
\text { a.d Vršac }\end{array}$ & $\begin{array}{l}\text { Production of } \\
\text { pharmaceutic } \\
\text { al } \\
\text { preparations }\end{array}$ & 1,77 & 25.608 & 18.635 & 18.922 & 17.200 & 14.435 & 19.970 & 20.814 \\
\hline $\begin{array}{l}\text { Valjaonica } \\
\text { Bakra }\end{array}$ & $\begin{array}{l}\text { Processing of } \\
\text { copper }\end{array}$ & 1,54 & 1.479 & 1.387 & 2.109 & 5.827 & 5.418 & 5.347 & 4.607 \\
\hline $\begin{array}{l}\text { Impol Seval } \\
\text { a.d., } \\
\text { Sevojno }\end{array}$ & $\begin{array}{l}\text { Processing of } \\
\text { aluminium }\end{array}$ & 1,36 & 3.605 & 2.702 & 2.721 & 2.483 & 2.109 & 1.639 & 1.394 \\
\hline $\begin{array}{l}\text { Siemens } \\
\text { d.o.o. } \\
\text { Beograd }\end{array}$ & $\begin{array}{l}\text { Wholesale of } \\
\text { other } \\
\text { machines }\end{array}$ & 1,34 & 2.922 & 3.261 & 2.564 & 2.332 & 1.541 & 1.069 & 1.165 \\
\hline $\begin{array}{l}\text { Tarkett } \\
\text { d.o.o. } \\
\text { Backa } \\
\text { Palanka }\end{array}$ & $\begin{array}{l}\text { Production of } \\
\text { construction } \\
\text { industry } \\
\text { elements }\end{array}$ & 1,27 & 10.078 & 12.307 & 13.109 & 14.607 & 12.930 & 11.144 & 12.852 \\
\hline $\begin{array}{l}\text { Ball } \\
\text { Pakovanja } \\
\text { Evropa } \\
\text { Beograd, } \\
\text { d.o.o. } \\
\end{array}$ & $\begin{array}{l}\text { Production of } \\
\text { light metal } \\
\text { packaging }\end{array}$ & 1,26 & 6.063 & 4.399 & 5.210 & 3.752 & 2.614 & 2.071 & 1.362 \\
\hline $\begin{array}{l}\text { Valy d.o.o. } \\
\text { Valjevo }\end{array}$ & $\begin{array}{l}\text { Production of } \\
\text { knitted and } \\
\text { crocheted } \\
\text { socks }\end{array}$ & 1,15 & 12.005 & 9.404 & 8.323 & 8.785 & 8.512 & 8.487 & 7.969 \\
\hline $\begin{array}{l}\text { Tetra Pak } \\
\text { Production } \\
\text { d.o.o. } \\
\text { Beograd }\end{array}$ & $\begin{array}{l}\text { Production of } \\
\text { corrugated } \\
\text { paper and } \\
\text { packaging }\end{array}$ & 1,01 & 3.957 & 2.319 & 1.849 & 1.972 & 1.023 & 1.058 & 3.118 \\
\hline
\end{tabular}

Source: Authors’ research based on data from SBRA (2016)

Table 6. Leading Serbian exporters financed by foreign direct investments-data on shareholders' equity

\begin{tabular}{|c|c|c|c|c|c|c|c|c|c|}
\hline \multirow[t]{2}{*}{ Company } & \multirow[t]{2}{*}{ Activity } & \multirow{2}{*}{$\begin{array}{l}\text { Share in } \\
\text { Serbia's } \\
\text { export } \\
2012\end{array}$} & \multicolumn{7}{|c|}{$\begin{array}{l}\text { SHAREHOLDERS' EQUITY } \\
\text { (in } 000000 \text { dinars) }\end{array}$} \\
\hline & & & 2015 & 2014 & 2013 & 2012 & 2011 & 2010 & 2009 \\
\hline $\begin{array}{l}\text { Fiat } \\
\text { Automobili } \\
\text { d.o.o. } \\
\text { Kragujevac }\end{array}$ & $\begin{array}{l}\text { Production of } \\
\text { cars }\end{array}$ & 3,48 & 30.708 & 30.708 & 30.708 & 30.704 & 25.358 & 14.351 & 14.351 \\
\hline $\begin{array}{l}\text { Tigar Tyres } \\
\text { d.o.o., Pirot }\end{array}$ & $\begin{array}{l}\text { Production of } \\
\text { vehicle tyres }\end{array}$ & 1,96 & 3.433 & 3.433 & 3.433 & 3.433 & 3.433 & 3.433 & 3.433 \\
\hline $\begin{array}{l}\text { Nis A.D. } \\
\text { Novi Sad }\end{array}$ & $\begin{array}{l}\text { Extraction of } \\
\text { crude oil }\end{array}$ & 1,91 & 81.530 & 81.530 & 81.530 & 87.128 & 87.128 & 87.128 & 87.128 \\
\hline $\begin{array}{l}\text { Hemofarm } \\
\text { a.d Vršac }\end{array}$ & $\begin{array}{l}\text { Production of } \\
\text { pharmaceutic } \\
\text { al } \\
\text { preparations }\end{array}$ & 1,77 & 11.293 & 10.230 & 10.230 & 10.230 & 10.230 & 10.230 & 10.230 \\
\hline $\begin{array}{l}\text { Valjaonica } \\
\text { Bakra }\end{array}$ & $\begin{array}{l}\text { Processing of } \\
\text { copper }\end{array}$ & 1,54 & 3.219 & 3.219 & 3.219 & 3.219 & 3.218 & 3.218 & 3.218 \\
\hline $\begin{array}{l}\text { Impol Seval } \\
\text { a.d., } \\
\text { Sevojno } \\
\end{array}$ & $\begin{array}{l}\text { Processing of } \\
\text { aluminium }\end{array}$ & 1,36 & 954 & 954 & 954 & 954 & 954 & 954 & 954 \\
\hline $\begin{array}{l}\text { Siemens } \\
\text { d.o.o. } \\
\text { Beograd }\end{array}$ & $\begin{array}{l}\text { Wholesale of } \\
\text { other } \\
\text { machines }\end{array}$ & 1,34 & 1.026 & 1.026 & 1.026 & 1.026 & 678 & 322 & 375 \\
\hline Tarkett & Production of & 1,27 & 4.348 & 4.348 & 4.348 & 4.410 & 4.410 & 4.410 & 2.626 \\
\hline
\end{tabular}




\begin{tabular}{|c|c|c|c|c|c|c|c|c|c|}
\hline $\begin{array}{l}\text { d.o.o. } \\
\text { Backa } \\
\text { Palanka }\end{array}$ & $\begin{array}{l}\text { construction } \\
\text { industry } \\
\text { elements }\end{array}$ & & & & & & & & \\
\hline $\begin{array}{l}\text { Ball } \\
\text { Pakovanja } \\
\text { Evropa } \\
\text { Beograd, } \\
\text { d.o.o. } \\
\end{array}$ & $\begin{array}{l}\text { Production of } \\
\text { light metal } \\
\text { packaging }\end{array}$ & 1,26 & 1.552 & 1.552 & 1.552 & 1.548 & 1.548 & 1.339 & 1.339 \\
\hline $\begin{array}{l}\text { Valy d.o.o. } \\
\text { Valjevo }\end{array}$ & $\begin{array}{l}\text { Production of } \\
\text { knitted and } \\
\text { crocheted } \\
\text { socks }\end{array}$ & 1,15 & 11.737 & 9.304 & 8.083 & 8.083 & 7.510 & 7.510 & 7.510 \\
\hline $\begin{array}{l}\text { Tetra Pak } \\
\text { Production } \\
\text { d.o.o. } \\
\text { Beograd } \\
\end{array}$ & $\begin{array}{l}\text { Production of } \\
\text { corrugated } \\
\text { paper and } \\
\text { packaging }\end{array}$ & 1,01 & 130 & 130 & 130 & 130 & 130 & 130 & 130 \\
\hline
\end{tabular}

Source: Authors' research based on data from SBRA (2016)

\section{Results and discussion}

The research results are presented in Table 7 and Table 8 . Table 7 shows the ROA values for the selected companies with FDI inflows in the Republic of Serbia and Table 8 shows the ROE values for the selected companies.

The ROA values trend in the observed period has been perceived according to the chain indices. ROA values trend in the observed period indicates that there is no general conclusion that foreign direct investments contributed to the ROA increase. On the contrary, ROA values significantly varied during this period. Either enormous increase or enormous decrease could be observed. Besides, there are companies that realised negative ROA values because of operating losses, and thus these would not be considered and discussed. By observing only positive chain indices obtained from positive ROA values, the following conclusions can be made:

- In the company Fiat Automobili d.o.o. Kragujevac, during the period 20092013, there existed operating losses and negative ROA values. In 2014, ROA increased by $107 \%$ compared to the 2013 , while in 2015 , ROA decreased by even 37\% compared to the previous year of 2014.

- In the company Tigar Tyres d.o.o. Pirot, in 2010 ROA decreased by 3\% compared to the 2009; in 2011 ROA decreased by even 30\% compared to the 2010; in 2012 ROA increased by 3\% compared to the 2011 and in 2013 it increased by $41 \%$ compared to the 2012; in 2014, there it was decreased by 42\% in comparison with 2013 and in 2015 increased again by 5\% compared to the previous year.

- In the company Nis a.d. Novi Sad, in 2010 a negative value of chain index was realised due to negative value of ROA in 2009; in 2011 it increased by $19 \%$ compared to the 2010, in 2012 it increased by 25\% compared to the 2011, while in 2013 it decreased by 26\% compared with the previous year and in 
2014, it was also decreased by $16 \%$ and in 2015 by even $53 \%$ compared to the previous year.

- In the company Hemofarm a.d. Vršac, in 2010, ROA decreased by $49 \%$ compared to the 2009; in 2011 it increased by 131\% compared to the 2010; in 2012 it increased by 5\% compared to the 2011, while in 2013 it decreased by $23 \%$ compared to the 2012 , and in 2014 , it was also increased by $28 \%$ so that in 2015, it was decreased again by $15 \%$ compared to the previous year.

- In the company Valjaonica bakra, in 2010 ROA decreased by $24 \%$ compared to 2009; in 2011 it increased by 21\% compared to 2010; in 2012 it decreased by $1 \%$ compared to 2011 ; in 2013 it decreased by $36 \%$ compared to 2012, in 2014 it decreased by even 76\% compared to 2013, while in 2015, it increased by enormous $626 \%$.

- In the company Impol Seval a.d., Sevojno, in 2010 ROA increased by as much as $581 \%$ compared to 2009 ; in 2011 it increased by only $1 \%$ compared to 2011 , while in 2012 it decreased by 24\% compared to 2011 and in 2013 it decreased by $40 \%$ compared to 2012 ; in 2014, it decreased by $6 \%$ compared to 2013 , and in 2015 it increased by $163 \%$.

- In the company Siemens d.o.o. Beograd, in 2010 the negative value of ROA was accomplished, hence the negative value of chain index; in 2011 positive value of ROA was accomplished, but due to negative value in 2010, negative chain index was obtained; in 2012 ROA increased by $112 \%$ compared to the 2011, while in 2013 ROA decreased by 18\%, and in 2014 it increased by $28 \%$, and in 2015 decreased again by 17\% compared to the previous year.

- In the company Tarkett d.o.o. Bačka Palanka, in 2010 ROA increased by 114\%; in 2011 ROA decreased by 28\%; in 2012 ROA increased by $2 \%$, in 2013 also increased by 5\% compared to the previous year, in 2014 ROA decreased by $44 \%$ compared to the previous year, while in 2015 ROA had the negative value.

- In the company Ball Pakovanja Evropa Beograd d.o.o., in 2010 ROA decreased by $22 \%$ compared to the 2009; in 2011 ROA decreased by $66 \%$, while in 2012 ROA increased significantly, by 310\% compared to the 2011, in 2013 ROA decreased again by $10 \%$ and in 2014 decreased by 16\% compared to the previous year, while in 2015, ROA increased by $14 \%$ compared to the previous year.

- In the company Valy d.o.o. Valjevo, ROA increased by 95\% compared to 2009; in 2011, the negative value of ROA was realised, so negative chain indices were recorded in 2011 and 2012; in 2013 ROA decreased by 54\% compared to 2012, in 2014 decreased by 36\% and in 2015 increased by 29\% compared to the previous year.

- In the company Tetra Pak Production d.o.o. Beograd, firstly there was the increase of ROA by $10 \%$ in 2010 compared to the 2009; in 2011 ROA decreased by 39\%; in 2012 it increased by 44\% compared to the 2011; in 2013 
it decreased by $28 \%$ compared to the 2012, while in 2014 it increased again by $27 \%$ and in 2015 by $24 \%$ compared to the previous year.

Hence, we could partially confirm the hypothesis H1. The reason is because in some observed companies, ROA had both positive and negative trends, as well. Dynamics of ROA values is graphically shown in Figure 1.

Table 7. ROA for companies with FDI inflows in the Republic of Serbia

\begin{tabular}{|c|c|c|c|c|c|c|c|c|c|c|c|c|c|c|}
\hline \multirow{2}{*}{ COMPANY } & \multicolumn{7}{|c|}{ RETURN ON ASSETS (ROA) IN \% } & \multicolumn{7}{|c|}{ CHAIN INDICES } \\
\hline & 2009 & 2010 & 2011 & 2012 & 2013 & 2014 & 2015 & 2009 & 2010 & 2011 & 2012 & 2013 & 2014 & 2015 \\
\hline $\begin{array}{l}\text { Fiat } \\
\text { Automobili } \\
\text { d.o.o. } \\
\text { Kragujevac }\end{array}$ & 0,57 & $-1,00$ & $-6,87$ & $-3,39$ & 1,52 & 3,14 & 1,98 & - & * & * & * & $*$ & 207 & 63 \\
\hline $\begin{array}{l}\text { Tigar Tyres } \\
\text { d.o.o., Pirot }\end{array}$ & 24,02 & 23,33 & 16,36 & 17,14 & 24,22 & 13,93 & 14,67 & - & 97 & 70 & 103 & 141 & 58 & 105 \\
\hline $\begin{array}{l}\text { Nis a.d. } \\
\text { Novi Sad }\end{array}$ & $-1,46$ & 14,79 & 17,65 & 21,99 & 16,21 & 13,63 & 6,35 & - & * & 119 & 125 & 74 & 84 & 47 \\
\hline $\begin{array}{l}\text { Hemofarm } \\
\text { a.d Vršac }\end{array}$ & 10,87 & 5,56 & 12,83 & 13,53 & 10,45 & 13,38 & 11,4 & - & 51 & 231 & 105 & 77 & 128 & 85 \\
\hline $\begin{array}{l}\text { Valjaonica } \\
\text { Bakra }\end{array}$ & 4,896 & 3,726 & 4,51 & 4,48 & 2,85 & 0,69 & 5,01 & - & 76 & 121 & 99 & 64 & 24 & 726 \\
\hline $\begin{array}{l}\text { Impol } \\
\text { Seval a.d., } \\
\text { Sevojno }\end{array}$ & 1,64 & 11,17 & 11,31 & 8,62 & 5,16 & 4,86 & 12,78 & - & 681 & 101 & 76 & 60 & 94 & 263 \\
\hline $\begin{array}{l}\text { Siemens } \\
\text { d.o.o. } \\
\text { Beograd }\end{array}$ & 6,66 & $-0,18$ & 4,311 & 9,15 & 7,46 & 9,53 & 7,88 & - & * & * & 212 & 82 & 128 & 83 \\
\hline $\begin{array}{l}\text { Tarkett } \\
\text { d.o.o. } \\
\text { Backa } \\
\text { Palanka } \\
\end{array}$ & 9,93 & 21,27 & 15,41 & 15,74 & 16,55 & 9,27 & $-1,21$ & - & 214 & 72 & 102 & 105 & 56 & * \\
\hline $\begin{array}{l}\text { Ball } \\
\text { Pakovanja } \\
\text { Evropa } \\
\text { Beograd, } \\
\text { d.o.o. } \\
\end{array}$ & 9,78 & 7,59 & 2,55 & 10,46 & 9,39 & 7,92 & 9,03 & - & 78 & 34 & 410 & 90 & 84 & 114 \\
\hline $\begin{array}{l}\text { Valy d.o.o. } \\
\text { Valjevo }\end{array}$ & 2,89 & 5,63 & $-0,71$ & 2,33 & 1,07 & 0,69 & 0,89 & - & 195 & * & -328 & 46 & 64 & 129 \\
\hline $\begin{array}{l}\text { Tetra Pak } \\
\text { Production } \\
\text { d.o.o. } \\
\text { Beograd }\end{array}$ & 49,59 & 54,38 & 32,96 & 47,6 & 34,42 & 43,82 & 54,33 & - & 110 & 61 & 144 & 72 & 127 & 124 \\
\hline
\end{tabular}

Source: Authors calculation

Note: The fields marked with * indicate the negative values of chain indices, or positive values calculated from negative ROA values in the current and previous year. 
Figure 1. Line diagram for ROA values for selected companies with FDI inflow in the Republic of Serbia

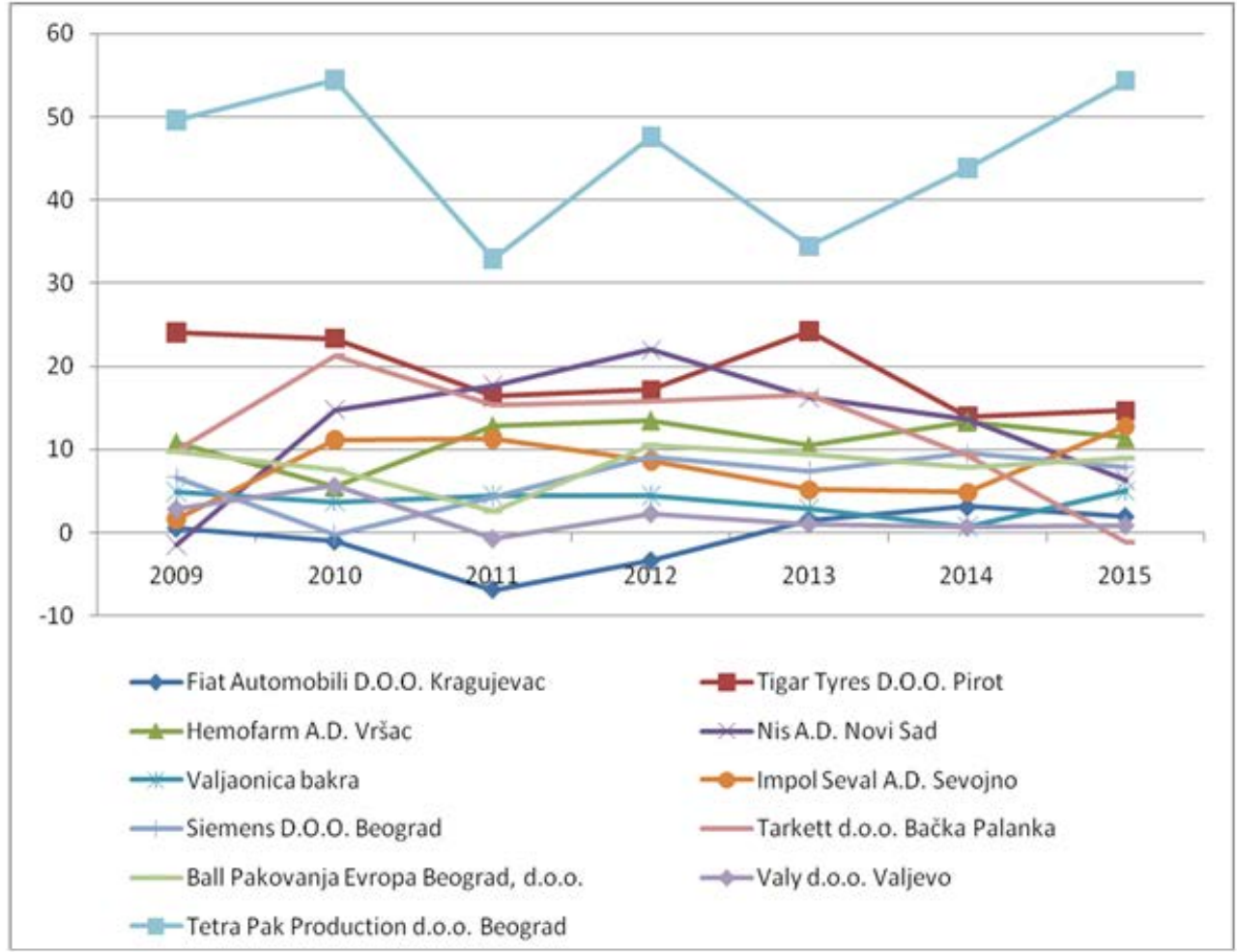

Source: Authors

The same could be said about ROE values. Several observed companies realised net loss in the observed period, so their ROE had negative values. Generally, ROE increased in 2010 and in 2012, but in most cases decreased in 2011 and in 2013. As shown in Table 8, ROE values significantly varied in the observed period, so it cannot be concluded that foreign direct investment has a positive impact on ROE values.

- In the company Fiat Automobili d.o.o. Kragujevac, in 2010, ROE increased by 193,4\% compared to 2009, in 2011 and in 2012 negative value of ROE was realised; in 2013, chain index of ROE value was negative, so it would not be discussed; in 2014, ROE increased by even 112\% and in 2015 decreased by $15 \%$ compared to the previous year.

- In the company Tigar Tyres d.o.o. Pirot, in 2010 ROE increased by 8\% compared to 2009; in 2011 ROA decreased by 39,6\% compared to 2010; in 2012 ROE decreased by 15,3\% compared to the 2011, in 2013 it increased by 
77,4\% compared to the 2012, in 2014 ROE decreased by 36\% and in 2015 increased again by $6 \%$ compared to the previous year.

- In the company Nis a.d. Novi Sad, in 2010 the negative value of chain index was accomplished due to the negative value of ROE in 2009; in 2011 the value increased by 32,6\% compared to the 2010, in 2012 it decreased by 22,2\% compared to 2011; in 2013 it decreased by 18,01\% compared to 2012, in 2014, ROE decreased by $47 \%$ and in 2015 decreased by $49 \%$ compared to the previous year.

- In the company Hemofarm a.d. Vršac, in 2010 and in 2011, ROE had the negative values; in 2012 the chain index was negative due to the negative value of ROE in 2011; in 2013, the value of ROE increased by $12,6 \%$ compared to 2012; in 2014, ROE decreased by $19 \%$ and in 2015 by $22 \%$ compared to the previous year.

- In the company Valjaonica Bakra, in 2010 ROE increased by $28,6 \%$ compared to 2009; in 2011 it increased by 39,4\% compared to 2010; while from 2012 to 2014, ROE had negative values and in 2015 chain index of ROE was also negative because of negative ROE value in the previous 2014 year.

- In the company Impol Seval a.d., Sevojno, in 2010 ROE increased by as much as $615,3 \%$ compared to 2009 ; in 2011 it increased by $48,9 \%$ compared to the 2010; in 2012 it decreased by 27,8\% compared to the 2011 and in 2013 it decreased by $38,9 \%$ compared to the 2012; in 2014, ROE decreased by $96,5 \%$, while in 2015, it increased by enormous $6362 \%$.

- In the company Siemens d.o.o. Beograd, in 2010 ROE decreased by $61,85 \%$ compared to 2009; in 2011, ROE increased by $69,4 \%$ compared to the 2010; in 2012, ROE increased by 154,8\% compared to the 2011, while in $2013 \mathrm{ROE}$ decreased by $52,5 \%$ compared to the previous year; in 2014, it increased by $137 \%$ compared to 2014 , and in 2015 decreased again by $40 \%$ compared to the previous year.

- In the company Tarkett d.o.o. Bačka Palanka, in 2010 ROE increased by $132,8 \%$ compared to the 2009; in 2011 ROE decreased by 2,7\% compared to the 2010; in 2012 ROE increased by 82,6\%, and in 2013 ROE decreased by $4,1 \%$ compared to the previous year; in 2014, it decreased by $4 \%$ and in 2015 by $27 \%$ compared to the previous year.

- In the company Ball Pakovanja Evropa Beograd d.o.o., ROE increased in 2010 by as much as 736,7\% compared to the 2009; in 2011 decrease of ROE of $62,7 \%$ could be observed, while in 2012 there was a significant increase of ROE of $137,7 \%$ compared to the 2011; in 2013 ROE again decreased by 7,81\%; in 2014, ROE had negative value and in 2015 chain index was also negative because of negative ROE value in the previous year.

- In the company Valy d.o.o. Valjevo, ROE increased by 323,6\% compared to 2009; in 2011, the value of ROE decreased by 95,25\% compared to 2010; in 2012, ROE increased by $217,2 \%$ compared to 2011 and in 2013 ROE 
increased by $36,9 \%$ compared to 2012; in 2014, ROE was negative and in 2015, chain index was negative because of negative ROE value in the previous year.

- In the company Tetra Pak Production d.o.o. Beograd ROE firstly increased by $96,9 \%$ in 2010 compared to 2009; in 2011, ROE decreased by 0,5\% compared to 2010; in 2012 there was an increase of 7,8\% compared to 2011; in 2013 there was a decrease of 0,5\% compared to 2012; in 2014, ROE increased by only $2 \%$ and in 2015 by $3 \%$ compared to the previous year.

Hence, we could partially accept the hypothesis H2. The reason for that is that there are companies in which ROE really had a positive trend in the observed period, but there are also companies in which ROE had both positive and negative trend, as well.

Dynamics of ROE values is graphically shown in Figure 2.

Table 8. ROE for companies with FDI inflows in the Republic of Serbia

\begin{tabular}{|c|c|c|c|c|c|c|c|c|c|c|c|c|c|c|}
\hline \multirow{2}{*}{ COMPANY } & \multicolumn{7}{|c|}{ RETURN ON EQUITY (ROE) IN \% } & \multicolumn{7}{|c|}{ CHAIN INDICES } \\
\hline & 2009 & 2010 & 2011 & 2012 & 2013 & 2014 & 2015 & 2009 & 2010 & 2011 & 2012 & 2013 & 2014 & 2015 \\
\hline $\begin{array}{l}\text { Fiat } \\
\text { Automobili } \\
\text { d.o.o. } \\
\text { Kragujevac }\end{array}$ & 0,61 & 1,79 & $-22,8$ & $-0,98$ & 4,88 & 10,33 & 8,78 & l & 293,4 & $*$ & $*$ & $*$ & 212 & 85 \\
\hline $\begin{array}{l}\text { Tigar } \\
\text { Tyres } \\
\text { d.o.o., } \\
\text { Pirot } \\
\end{array}$ & 36 & 38,9 & 23,5 & 19,9 & 35,3 & 22,43 & 23,78 & l & 108 & 60,4 & 84,7 & 177,4 & 64 & 106 \\
\hline $\begin{array}{l}\text { Nis a.d. } \\
\text { Novi Sad }\end{array}$ & -117 & 35 & 46,4 & 36,1 & 29,6 & 15,7 & 7,93 & l & * & 132,6 & 77,8 & 81,99 & 53 & 51 \\
\hline $\begin{array}{l}\text { Hemofarm } \\
\text { a.d Vršac }\end{array}$ & 16,8 & $-4,22$ & $-38,3$ & 16,23 & 18,28 & 14,89 & 11,64 & l & * & * & * & 112,6 & 81 & 78 \\
\hline $\begin{array}{l}\text { Valjaonica } \\
\text { Bakra }\end{array}$ & 0,77 & 0,99 & 1,38 & $-3,87$ & $-70,9$ & $-51,9$ & 6,22 & l & 128,6 & 139,4 & * & * & * & * \\
\hline $\begin{array}{l}\text { Impol } \\
\text { Seval a.d., } \\
\text { Sevojno }\end{array}$ & 2,09 & 14,95 & 22,27 & 16,08 & 9,82 & 0,34 & 25,03 & I & 715,3 & 148,9 & 72,2 & 61,1 & 3,5 & 7362 \\
\hline $\begin{array}{l}\text { Siemens } \\
\text { d.o.o. } \\
\text { Beograd }\end{array}$ & 11,56 & 4,41 & 7,47 & 19,03 & 9,03 & 21,39 & 12,81 & 1 & 38,15 & 169,4 & 254,8 & 47,5 & 237 & 60 \\
\hline $\begin{array}{l}\text { Tarkett } \\
\text { d.o.o. } \\
\text { Backa } \\
\text { Palanka } \\
\end{array}$ & 16,17 & 37,64 & 36,64 & 66,89 & 64,21 & 61,54 & 44,94 & I & 232,8 & 97,3 & 182,6 & 95,9 & 96 & 73 \\
\hline $\begin{array}{l}\text { Ball } \\
\text { Pakovanja } \\
\text { Evropa } \\
\text { Beograd, } \\
\text { d.o.o. }\end{array}$ & 4,09 & 34,22 & 12,77 & 30,35 & 27,98 & $-18,4$ & 27,44 & I & 836,7 & 37,3 & 237,7 & 92,19 & * & * \\
\hline $\begin{array}{l}\text { Valy d.o.o. } \\
\text { Valjevo }\end{array}$ & 1,44 & 6,10 & 0,29 & 0,92 & 1,26 & $-1,58$ & 1,38 & I & 423,6 & 4,75 & 317,2 & 136,9 & * & * \\
\hline
\end{tabular}




\begin{tabular}{|l|c|c|c|c|c|c|c|c|c|c|c|c|c|c|}
\hline $\begin{array}{l}\text { Tetra Pak } \\
\text { Production } \\
\text { d.o.o. } \\
\text { Beograd }\end{array}$ & 43,96 & 86,54 & 86,08 & 92,78 & 92,29 & 93,86 & 96,4 & $/$ & 196,9 & 99,5 & 107,8 & 99,5 & 102 & 103 \\
\hline
\end{tabular}

Source: Authors calculation

Note: The fields marked with * indicate the negative values of chain indices, or positive values calculated from negative ROE values in the current and previous year.

Figure 2. Line diagram for ROE values for selected companies with FDI inflow in the Republic of Serbia

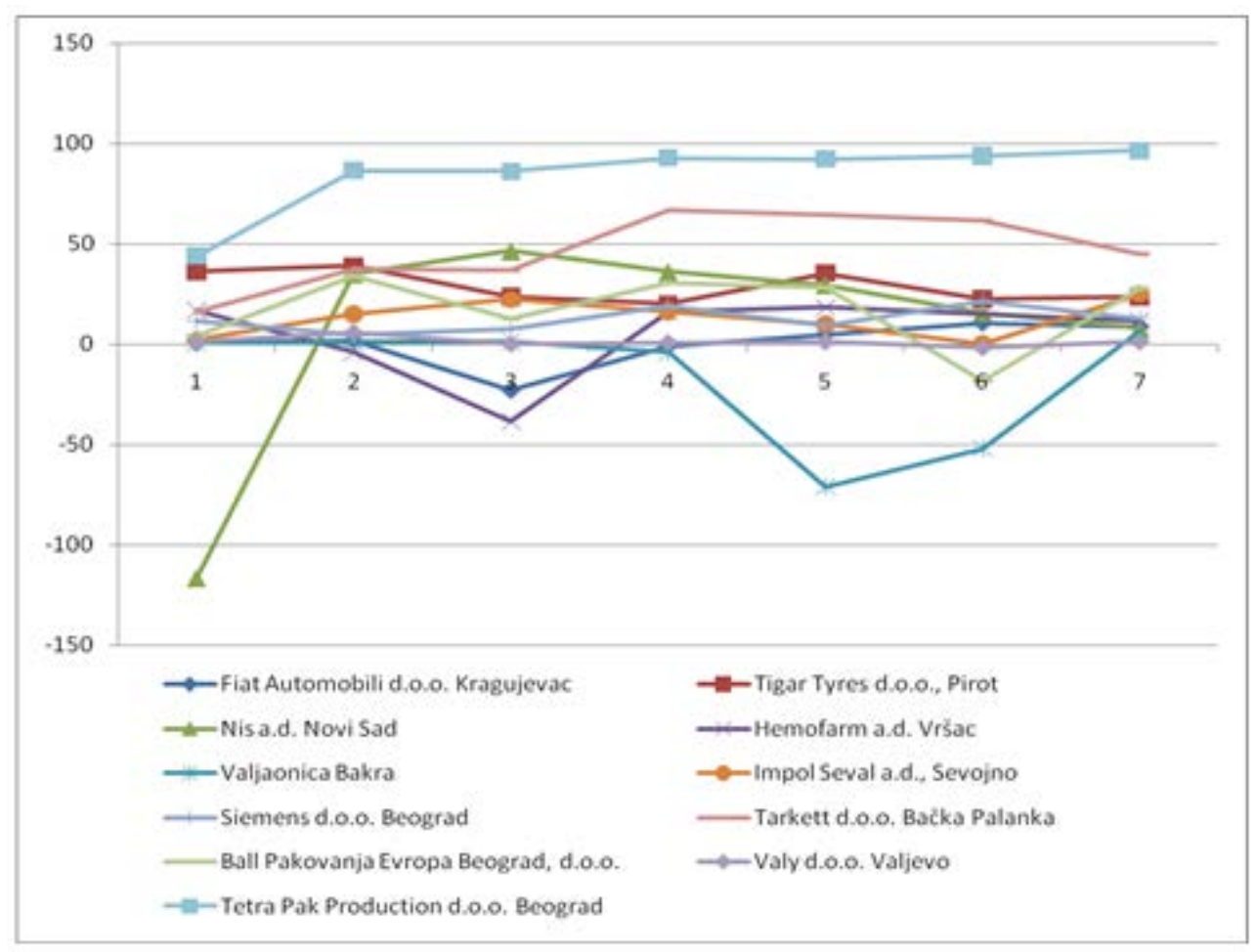

Source: Authors

\section{Conclusion}

The paper shows that the analysis of FDI effects has been the subject of numerous theoretical and empirical researches which revealed that FDI inflows might bring many positive effects to the economies of host countries and their companies. The findings of a quite a number of researches show that foreign-owned companies, especially majority foreign-owned ones (which experienced FDI inflows) 
accomplish better business performances than other domestic and state-owned companies.

The positive effects that FDI might bring stimulated countries, including Serbia, to try to attract more FDI inflows. Inflows of foreign investment in Serbia mainly developed through privatisation process, which most often implied participation of foreign investors in purchase of domestic companies that had been the subject of privatisation. As exporters are the core of national economy, the paper has been focused on export companies - those in which there has been an inflow of FDI and which are in majority foreign ownership. Also, the research aim has been to estimate the profitability of leading Serbian exporters financed by foreign direct investments.

The results show that, starting with the experience of leading Serbian exporters, it is not enough only to attract FDI in order to accomplish the expected positive effects on business and performance of the company. It is also important how FDI will be embedded in the individual company, how the foreign capital inflow and change of ownership structure will influence its operating (differently for different companies, obviously) and what the resulting effects will be in various business aspects. In the case of Serbian exporters, the results vary, both per companies and per individual years.

The research results show that there is no general conclusion that foreign direct investments contributed to the Serbian exporters' profitability increase. On the contrary, the most common used profitability measures like return on assets (ROA) and return on equity (ROE) significantly varied during this period. Either enormous increase or enormous decrease could be observed. Besides, there are companies that realised negative ROA values because of operating losses and negative ROE values because of net losses. Five companies: Fiat automobili d.o.o. Kragujevac, Nis a.d. Novi Sad, Siemens d.o.o. Beograd, Tarkett d.o.o. Bačka Palanka, Valy d.o.o. realised operating losses in the observed period from 2009 to 2015. Also, five companies: Fiat automobili d.o.o. Kragujevac, Hemofarm a.d., Vršac, Valjaonica Bakra, Ball Pakovanja Evropa Beograd, d.o.o., and Valy d.o.o. realised net losses during the observed period.

There is no general conclusion that foreign direct investments contributed to the ROA increase. Conversely, ROA values significantly varied during this period. Either enormous increase or enormous decrease could be observed.

As to the ROE, it might be concluded that it increased in 2010 and in 2012, but in most cases decreased in 2011 and in 2013. ROE values significantly varied in the observed period, so it cannot be concluded that foreign direct investment has a positive impact on ROE values. Thus, it could be concluded that both defined hypotheses have been confirmed partially. 
However, there are some research limitations. Despite the advantages of accounting-based measures, there are also disadvantages. First, it must be pointed out that accounting profit is the narrowest measure of performance. Then, different studies use different accounting performance measures and make it difficult to compare the results. In addition, accounting measures are supposed to be only a reflection of the performance in the past. There is also the problem of comparing data with other selected methodology.

In future, in order to evaluate the performance of the company with FDI inflow, it should be necessary to consider other financial and non-financial measures in the way it is explained in contemporary performance measurement and management models like Balanced Scorecard model is.

\section{References}

Aghion, P. \& Blanchard, J. O. (1998). On privatization methods in Eastern Europe and their implications. Economics of Transition, 6(1), 87-99.

Caves, R. (1974). Multinational firms, competition and productivity in the host country. Economica, 41, 176-193.

Caves, R. (1996). Multinational enterprise and economic analysis. Cambridge: Cambridge University Press.

Frydman, R., Cheryl, W., Gray, M. H. \& Rapaczynski, A. (1999). When does privatization work? The impact of private ownership on corporate performance in transition economies. Quarterly Journal of Economics, November, 1153-1192.

Grosfeld, I. \& Tressel, T. (2002). Competition and ownership structure: Substitutes or complements? Evidence from the Warsaw stock exchange. The Economics of Transition, 10(3), 525-551.

Hunya, G. (2000). International competitiveness impacts of FDI in CEECs (Research Reports 268), Vienna: Institute for International Economic Studies.

Hunya, G. (2002). Recent impacts of foreign direct investment on growth and restructuring in Central European transition countries (Research Reports 284), Vienna: Institute for International Economic Studies.

Kalotay, K. (2010). Patterns of inward FDI in economies in transition. Eastern Journal of European Studies, 1, 55-76.

Kaplan, R. S. \& Norton, D. P. (1992). The balanced scorecard: Measures that drive performance. Harvard Business Review, 70, 71-79.

Kaplan, R. S. \& Norton, D. P. (1993). Putting the balanced scorecard to work. Harvard Business Review, Volume 71(5), 134-142.

Kaplan, R. S. \& Norton, D. P. (1996). The balanced scorecard: Translating strategy into action. Boston: Harvard Business School Press.

Kennerly, M. \& Neely, A. (2003). Measuring performance in a changing business environment. International Journal of Operations and Production Management, 23, 213-229.

Kocenda, E. \& Svejnar, J. (2002). Ownership and firm performance after large-scale privatization (Working paper No. 471a), Michigan: The William Davidson Institute. 
Lizal, L. \& Svejnar, J. (2001). Investment, credit rationing, and the soft budget constraint: Evidence from Czech panel data. The Review of Economics and Statistics, 84, 353370.

Lizal, L., \& Svejnar, J. (2002). Privatization revisited: The effects of foreign and domestic owners on corporate performance (Third draft, June 2002), Michigan: The William Davidson Institute.

National bank of Serbia (NBS). (2016). Retreived from http://www.nbs.rs/ on 05/02/2016.

Paranjape, B., Rossiter, M. \& Pantano, V. (2006). Performance measurement systems: Successes, failures and future- A review. Measuring Business Excellence, 10(3), 414.

Privatization Agency (2013). Analysis of the privatization effects in Serbia. Retreived from http://www.priv.rs/cms/view.php?id=9319 on 05/02/2016.

Rappaport, J. (2000). How does openness to capital flows affect growth? (Research Working Paper 00-11), Kansas City: Federal Reserve Bank.

Serbian Business Register Agency (SBRA). (2016). Retreived from www.apr.gov.rs on 01/10/2016.

Smith, S. C., Beon-Cheol, C. \& Vodopivec, M. (1997). Privatization incidence, ownership forms, and firm performance: Evidence from Slovenia. Journal of Comparative Economics, 25, 158-179.

Tangen, S. (2005). Analysing the requirements of performance measurement systems. Measuring Business Excellence, 9(4), 46-54.

Taticchi, P., Tonelli, F., \& Cagnazzo, L. (2010). Performance measurement and management: A literature review and research agenda. Measuring Business Excellence, 14(1), 4-18.

UNCTAD FDI database.

\section{EFEKTI STRANIH DIREKTNIH INVESTICIJA NA PROFITABILNOST PREDUZEĆA IZVOZNIKA U REPUBLICI SRBIJI}

Apstrakt: Napori na privlačenju stranih direktnih investicija iz inostranstva za Republiku Srbiju došli su do izražaja sa otpočinjanjem procesa tranzicije. Proces vlasničke transformacije u Republici Srbiji najčešce je uključivao prilive stranih direktnih investicija, jer je podrazumevao učešce stranih investitora $u$ kupovini domaćih preduzeća koja su bila predmet privatizacije. Predmet istraživanja u radu je iskustvo Republike Srbije u privlačenju stranog kapitala u lokalne izvozne kompanije, sa posebnim osvrtom na efekte stranog kapitala na profitabilnost tih kompanija. Cilj rada je da oceni profitabilnost vodećih srpskih izvoznika finansiranih stranim direktnim investicijama, odnosno da odredi da li i do koje mere su strane direktne investicije doprinele porastu prinosa na aktivu i prinosa na kapital, kao osnovnih merila profitabilnosti.

Rezultati istraživanja pokazuju da, u slučaju srpskih izvoznika, profitabilnost varira, i po kompanijama i po pojedinim godinama. Ne može se dati generalni zaključak da strane direktne investicije doprinose porastu stope prinosa na aktivu. Naprotiv, vrednosti stope prinosa na aktivu značajno variraju tokom 
posmatranog perioda. Može se uočiti i njihov veliki porast i veliko opadanje. Isto se uočava i za vrednosti stope prinosa na kapital.

Ključne reči: izvoznici, strane direktne investicije, profitabilnost, stopa prinosa na aktivu, stopa prinosa na kapital, Republika Srbija.

\section{Authors' biographies}

Violeta Domanović is an Associate Professor at the Faculty of Economics, University of Kragujevac, Department of Management and Business Administration. She graduated from the Faculty of Economics, University of Kragujevac, Department of Economic Statistics and Informatics, in 1997. She defended her Master's thesis entitled The economic effects of alternative corporate strategies and got her M.B.A. in Management and Business administration at the Faculty of Economics, University of Kragujevac, in 2002. $\mathrm{Ph} . \mathrm{D}$. thesis entitled Balanced scorecard and activity-based management in function of corporate efficiency improvement defended in 2009 at the Faculty of Economics, University of Belgrade and received her Ph.D. degree, in the field of business economics. Key areas of her scientific interests include performance measurement and management and cost management. Since 2011, she has been working on the project of integrated and interdisciplinary research under the auspices of the Ministry of Science and Technological Development of Serbia, CIII 41010 Preclinical Testing of Bioactive Substances (PIBAS), subproject entitled Management and Marketing Research as a Support of the Interdisciplinary Projects Implementation.

Sandra Stojadinović Jovanović is an Assistant Professor at the Faculty of Economics, University of Belgrade, in Department for International Economic Relations. She graduated from the Faculty of Economics in Kragujevac (1997), completed Master course in International Economics at the Faculty of Economics in Belgrade (with master thesis entitled Transnationalisation of International Trade) in 2007 and acquired a Ph.D. title at the Faculty of Economics in Belgrade (with Ph.D. thesis entitled New Approach in the International Trade Analysis) in 2010. Her fields of interests are: foreign direct investments, transnational companies, international trade and globalization. She is a member of the Scientific Society of the Serbian Economists. Currently her research work is supported by the Serbian Ministry of Education, Science and Technological Development through the project entitled The Role of Contemporary Management and Marketing Methods in Improvement of Competitiveness of the Companies in Serbia within the Process of its Integration to the European Union (project no. 179062). 